\title{
The Influence of Head Librarians' Leadership Styles on Job Satisfaction of Librarians' in Tertiary Institution Libraries in Imo State, Nigeria
}

\author{
Uchenna Nwaigwe \\ Alvan Ikoku Federal College of Education, Owerri, Nigeria \\ Email: successismine10@gmail.com
}

Received 2 June 2015; accepted 23 June 2015; published 29 June 2015

Copyright (C) 2015 by author and OALib.

This work is licensed under the Creative Commons Attribution International License (CC BY). http://creativecommons.org/licenses/by/4.0/

(c) (i) Open Access

\begin{abstract}
A general opinion that is supported by research is that leadership style in any organization exerts a major influence on the structure, strategy and well being of the organization. In the library environment therefore, the influence of leadership style on the job satisfaction of librarians is very crucial to the success of the library. Common observations from informal interactions with librarians who work in the libraries show that leadership styles in tertiary institution libraries in Imo state are poor and ineffective. This research work therefore investigated the influence of head librarians' leadership styles on librarians' job satisfaction in tertiary institution libraries in Imo State, Nigeria. The survey research design was adopted, while four research questions guided the investigation. The population of study consists of all librarians working in tertiary institution libraries in Imo State. Instrument for data collection was a four point questionnaire, designed by the researcher. Sixty-five questionnaires were distributed, while sixty-one were returned. Data collected were analyzed using mean and percentage where applicable. The findings of the study revealed a strong influence between head librarians' leadership styles and librarians' job satisfaction. Some recommendations were made to improve librarians' job satisfaction.
\end{abstract}

\section{Keywords}

Leadership, Leadership Styles, Job Satisfaction

Subject Areas: Library, Intelligence and Philology

\section{Introduction}

In this changing and challenging world where knowledge based economy is craving more intellectual property,

How to cite this paper: Nwaigwe, U. (2015) The Influence of Head Librarians' Leadership Styles on Job Satisfaction of Librarians' in Tertiary Institution Libraries in Imo State, Nigeria. Open Access Library Journal, 2: e1572.

http://dx.doi.org/10.4236/oalib.1101572 
the library plays a paramount role, by the provision, processing, packaging and dissemination of information materials. However, the success of the library in achieving these roles effectively, rests upon the leadership of the library. A leader is a person who takes the central roles in interaction and who influences the behaviour of other members of a group. He is that individual who has authority over others and is responsible for guiding their actions (Fatokun, Salaam, Ajegbomogun \& Adedipe, 2010) [1].

Leadership style is concerned with the initiation, organization and direction of the actions of the members of a group in a specific situation towards achieving the objectives of the group (Adegbesan, 2013) [2]. It is the ability to get work done with the group, while at the same time, winning the confidence, loyalty, respect and willing cooperation of the entire group. It is a process whereby an individual influences a group of individuals to achieve common goals (Northouse, 2007) [3]. Through leadership, teams are built and right decisions that ultimately affect the growth of the library are made. So decisions of leadership permeate every facet of an organization and hence its importance (Chukwuma \& Idris, 2009) [4].

Leadership has however assumed greater importance in today's organizations including the library because of the emergence of forces like globalization, competition, technological innovations and workers expectations. These forces require dynamic and efficient leadership, anchored on strong ability to not only combine resources in the most efficient ways, but to build a formidable work force that will work with enthusiasms for the achievement of goals. Different organizations including the library vary in their styles of leadership. The leadership style of the leader gives an organization its vision and ability to translate the vision into reality (Eneh, 2008) [5]. Leadership involves inducement, persuasion and motivation of subordinates to enable them contribute willingly to the organizational goals based on the employee's maximum capabilities (Nwachukwu, 2004) [6].

However, there is no known universally accepted style of leadership rather an appropriate style depends on situations and circumstances. The influence of any style of leadership on the work force, especially on the subordinate librarians will come to bear if the library leadership will achieve set goals. This is because followers are influenced when leadership and followership are properly linked (Vecchio, 2007) [7]. And in this respect, the job satisfaction of the librarian comes to bear in order to properly link leadership with followership in tertiary institution libraries.

Job satisfaction on the other hand as defined by Rezalean, Givi, Givi \& Nasarabadi (2010) [8] is an employees' general attitude towards his or her job. Smith (2012) [9] noted that it referred to the effective response of the worker to his job. Job satisfaction therefore is an important concern for all head libraries if they wish to have a satisfied staff. This means that satisfaction results from consequences of the workers' experience on the job in relation to the provision of those things that they consider important.

\subsection{Statement of Problem}

A general opinion that is supported by research is that leadership in any organization exerts a major influence on the structure, strategy and well being of the organization. Different leaders use different leadership styles and motivation strategies based on their personality, orientation, experience, culture, training and development to lead others. In the library like other organizations, each leadership style has effect on the job satisfaction of librarians, who are the engines saddled with the herculean task of bringing library vision and mission into reality.

The influence of leadership style on the job satisfaction of librarians is crucial to the success of the library. A good understanding of this influence is vital in supporting human resources development in libraries and is likely going to be a key factor in determining the success of both the head librarian as a leader, his subordinate librarians' and the library organisation. Common observations from informal interactions with librarians who work in the libraries show that leadership styles in tertiary institution libraries are poor and ineffective. So the librarians in these libraries who are saddled with the responsibility of providing effective services are perhaps not satisfied with their jobs. The problem of this study therefore is to determine the influence of leadership styles on job satisfaction of librarians.

\subsection{Significance of Study}

The influence of leadership styles on job satisfaction of librarians is significant to the field in that it builds upon the available body of knowledge and will help library leaders adopt the style that will enhance their leadership behaviours, as well as improve their motivation strategies. It will be beneficial in upgrading the quality of leadership and services offered in the libraries, when the relationship between leadership styles and job satisfaction 
of librarians is identified. Through the study, library leadership will also understand some job satisfaction strategies that are influenced by leadership style.

This study will also help give feed back to library leadership and help promote it, as well as understand the most preferred leadership style among subordinate librarians, which will ultimately lead to their job satisfaction. Above all, the result of the study will help to parcel a path for library schools to continue examining the need to establish leadership education programmes for library leaders, as well as the reviewing of library school programmes to reflect current issues and trends in leadership.

\subsection{Research Questions}

The study will be guided by the following research questions:

1) Which leadership style is most commonly adopted by head librarians in tertiary institution libraries in Imo State?

2) What influence do head Librarians democratic leadership style have on job satisfaction of librarians in tertiary institution libraries in the state?

3) What influence do head Librarians autocratic leadership style have on job satisfaction of librarians in tertiary institution libraries in the state?

4) What influence do head Librarians laissez-faire leadership style have on job satisfaction of librarians in tertiary institution libraries in the state?

\section{Review of Related Literature}

\subsection{Leadership}

The success of any organization is highly rested upon the leadership of the organization and its impact is desirable in organizations to aid easy and maximum success. No organization or group of any size or duration can exist without leaders. Someone has to organize meetings, determine and implement policies, represent the group and its decisions to other organizations or public and make the countless small contributions that are necessary to carry out its aims (Ekpenyong, 2003) [10]. However, the need to strike a balance between the leadership and followership is of essence, because it is the willingness of people to follow that makes a person a leader (Adegbesan, 2013) [2].

People generally follow those they perceive to be providing means of achieving their own desires, wants and needs. Leadership plays an important role in delivering the responsibility rather than focused on the authority and command when dealing with subordinates. A leader therefore must be a person who has the ability to guide their employees and direct their behaviour (McEachen \& Keogh, 2007) [11]. To be able to guide and direct effectively, the head librarian must demonstrate good leadership. This is because leadership entails the ability to communicate the value, vision and mission of the organization in order to motivate employees (Borkowski, Decker, Weber, Padro and Loungo (2011) [12]. One function of the head librarian above all is to use his leadership style to persuade and coordinate all activities of subordinates to willingly contribute to organizational goals in accordance with their maximum capabilities. The leadership style is therefore demonstrated in the leader's activities, which make him to be recognized as a leader of the group (Adegbesan, 2013) [2].

\subsection{Leadership Styles}

Leadership styles focus largely on the relationship between the leaders and the followers. Haralombus (2001) [13] is of the view that leadership style in practical sense of leading is important in that by leading effectively, the leader fulfils his basic needs, his individuality and humanity (and thereby help in the development of the human potentials of the workers as social beings, as creators and as master of mature). Sabnett \& Ross (2007) [14] submitted that leadership styles are important for effectiveness of service and directors should possess leadership styles to appropriately lead and manage their departments. The style of leadership of a leader is therefore concerned with the initiation, organization and direction of the actions of the members of a group in a specific situation towards achieving the goals of the group. Limsila \& Ogunlana (2007) [15] indicated that an appropriate leadership style leads to employee satisfaction and it is a good indicator to prove that a better style might lead employees to work effectively.

Leadership styles have different effects on the emotions of target followers and the most effective style a 
leader can use is a good mix that is customized to the situation. The leadership style of the head librarian should be based on a combination of beliefs, values and preferences as well as organizational culture and norms. According to Pearce 11 \& Robinson (2005) [16] leadership style while seemingly vague and esoteric, is an essential element in effective strategy implementation. It is central to any organization private or public. The leadership challenge is about how leaders mobilize others to want to get extra ordinary things done in organization. It is all about the practice leaders use to transform values into actions, visions into realities, obstacles into innovations, separateness into solidarity and risks into rewards (Kouzes, \& Posner, 2002) [17].

Leadership creates the climate in which people turn challenging opportunities into remarkable success through their influence. Effective leadership style might contribute to the success in completing task given (Gharehbaghi \& McManus, 2003) [18]. According to Khandwalls (1992) [19], it has been repeatedly observed that leadership style plays a critical role in the success or failure of an establishment and has been considered an important element affecting organizational performance. Library heads are therefore at liberty to choose a leadership style that will motivate and bring out the very best from subordinates. Vigoda \& Cohen (2003) [20] pointed out that job satisfaction and leadership style could improve the relationship between employees and employers. And the effect of such improved relationship on the overall goals and objectives of the library cannot be over emphasized.

Different leadership styles have been propounded by early and late theorist, but three basic style of leadership can be identified. Fatokun, Salaam, Ajegbomogun \& Adedipe (2010) [1] named them as autocratic, democratic and laissez-faire.

1) Autocratic - this style is characterized by authoritarian behaviour, unilateral decision making, one way communication and the denial of conflict. The leader acts as an absolute monarch with unlimited authority. This style is also known as the authoritarian style (Adeyemi, 2011) [21]. The leader directs the group members on the way things should be done. There is no delegation of authority to subordinates with the style (John, 2002) [22].

2) Democratic - this style involves shared decision making, open communication and realization that conflict is inevitable and must be managed. Although the leader maintains final authority, subordinates input and consultation is highly valued. The leader attempts as much as possible to make each individual feel that he is an important member of the organization. This style enhances staff morale according to Mba (2004) [23]. This style is also known as participative style.

3) Laissez-faire - this style allows subordinates maximum authority in their job. Individual decision making, free exchange of information and minimal leadership control and standard. Group members have freedom to do what they like and the leader does not interfere with or participate in the course of events determined by the group. The style is also known as free-reign.

However, despite the leadership styles available, studies have confirmed no one style is most effective in all situations. There is this often held speculation that some secrets lie in the style of the leader and the situation and yet others lay more emphasis on the personality and behaviour of the leader. What is paramount however for the library is that the head librarian must choose a style that will make subordinates happy with their0 jobs, and through it willingly contribute effectively to the achievement of library goals.

\subsection{Job Satisfaction}

Leadership style is an important determinant of employee job satisfaction and its concept in decision making process, goal setting, will influence authority and responsibility as a desire for job satisfaction. The happier people are with their jobs and the job environment, the more satisfied they are on the job. Satisfaction is therefore central in any work setting, to enable the work flow move with ease. Smith (2012) [9] sees job satisfaction as an effective response of the worker to his job. By this, it is meant that satisfaction results from consequences of the worker's experience on the job in relation to his own values and needs. For Vroom (2010) [24], job satisfaction is the affective orientation of individuals towards work roles that they are presently occupying. And it is achieved if the job fulfils the employees' dominant needs and is consistent with his expectations and values.

Fields (2002) [25] understands it to mean an employees' affective reaction to a job based on a range of elements. It is how much a person likes a job or a task they are doing (Hughes, Gonnett \& Curphy, 2006) [26]. Satisfaction with one's job can mean an increased involvement and fulfillment on the job and above all, create and produce greater willingness in employees to invest personal energy and time on the job. Razalean, Givi, Givi \& Nasrabadi (2010) [8] share this understanding when they concluded that job satisfaction leads an employee to be 
more productive, innovative and dedicated to maintaining the quality services offered to users. Job satisfaction is a part of life satisfaction and the nature of one's environment off the job. This view is supported by Ajayi (2012) [27] when he opined that job is an important part of life and job satisfaction influences one's general life satisfaction.

It can therefore be inferred that librarians who are not satisfied with their jobs, are likely to have issues with other aspects of their life including efficiency on their job. Job satisfaction is an important concern for employers as it is believed that satisfied employees are more likely to show up for work , have higher levels of performance and will stay with the organisation (Robbin, Decanzo \& Coulter, 2010) [28]. Leadership can therefore been seen as the relationship between what one wants from one's job and what one perceives it as offering. Emery \& Barker (2007) [29] while considering the importance of job satisfaction summed it as an end state of feelings. Employees are therefore satisfied with leaders who are concerned, considerate and supportive of these desires than those who are either indifferent or critical towards their desires and needs. Negative leader-employee relationship reduce productivity, increase absenteeism and turnover of the organization can be quite high (Ribelin, 2003) [30].

\subsection{Job Satisfaction Motivators}

Tella, Ayeni \& Popoola (2007) [31] opined that the job satisfaction of the librarian is naturally dependent on the economically, social and cultural conditions in a given country. So job satisfaction is only mentioned if some other elements exist in a place of harmony in the library environment. It can be influenced by many factors such as: the working conditions, work itself, supervision, policy and administration, advancement, compensation, interpersonal relationships, recognition and empowerment (Castillo \& Cano, 2004) [32].

According to Omolayo \& Ajila (2012) [33] there are varieties of factors that can influence a person's level of job satisfaction. Some of these factors include the level of pay and benefits, the perceived fairness of the promotion system within the organization, the quality of the working conditions, leadership and social relationships and the job itself (the variety of tasks involved, the interest and challenge the job generates and the clarity of the description and requirements). Job satisfaction comes from a combination of internal and external motivations. These motivating factors can include salary, working conditions, organizational climate and leadership styles amongst others.

Other influences on job satisfaction include the management style and culture, employee involvement, empowerment and autonomous work position. For the library like other organisations, job satisfaction will promote healthy library environment if other factors that enhance job satisfaction are properly figured into the job so the head librarian must never loose sight of those factors. Yarmohammadian \& Rad (2006) [34] consider factors that contribute to job satisfaction to consist of: wages, benefits, accomplishment, independence, acknowledgement, communication, working job conditions, job importance, co-workers, professionalism, organizational climate, relationship, working for a reputable agency, supervisor support, positive job security, work place flexibility, team environment and genetic factors.

Job dissatisfaction on its part has been noted as a great predicator of quitting a job. While job satisfaction promotes healthy library environment that will afford the librarian the opportunity to give in the best of his capabilities, a librarian who cannot meet some expectations with regards to his job will become dissatisfied and it will affect the library to a great extent. For any worker, job dissatisfaction can result in feelings of helplessness, burn out, resentment, anger and fatigue (Wilkinson \& Wagner, 1993) [35].

From the review of literature, there is a consensus of opinion that leadership styles can affect job satisfaction. The influence of leadership style and job satisfaction is crucial to the success of the library. A good understanding of this influence is vital in supporting human resources development in libraries and is likely going to be a key factor in determining the success of both the head librarian as a leader, his subordinate librarians' and the library organisation. The focus of this research therefore, is to determine the influence of leadership styles of head librarians on job satisfaction of librarians’ working in tertiary institutions libraries in Imo state.

\subsection{Methodology}

The study adopted the survey research design. The study population comprises all librarians’ working in tertiary institution libraries in Imo state, with a population of sixty-five (65). The instrument used for the study was a researcher-developed questionnaire, titled “Leadership Styles and Job Satisfaction of Librarians” (LSJSL), and 
based on four research questions. The instrument was given a face validity check by the Supervisor and further validated by two experts in measurement and evaluation in the School of Education at Alvan Ikoku Federal College of Education, Owerri. The questionnaire for data collection was a four point scale and sixty-five copies were distributed, while sixty-one copies were returned. Data collected were analyzed using mean and simple percentages where applicable.

\subsection{Data Analysis}

\section{Research Question 1}

Which leadership style is the most commonly adopted by head librarians in tertiary institutions libraries in Imo state?

Analysis of the Table 1 below indicates that democratic leadership style is most commonly used by head librarians in the libraries under study. This is shown in the response rate of 33 (54\%) from respondents who indicated that democratic leadership style is the most common leadership style used in tertiary institution libraries in Imo state. Autocratic leadership style ranked second with 18 (30\%) while laissez-faire ranked third with 10 (16\%).

\section{Research Question 2}

What influence do head Librarians' democratic leadership style have on job satisfaction of librarians?

From Table 2 below, question items 1, 2, 4, 5, showed mean values which were greater than 2.50, while question items 3 and 6 indicated mean value scores of below the criterion mean score of 2.50 which implies that democratic leadership style has positive influence on librarians' job satisfaction.

Research Question 3

What influence do head Librarians autocratic leadership style have on job satisfaction of librarians?

Table 3 indicates that question items 7, 8, 9, 11, were rated positive while question items 10 and 12 was rated negative. The mean scores were above and below the criterion mean of 2.50 respectively and this implies that head librarians autocratic leadership style affects librarians' job satisfaction negatively.

Research Question 4

What is the influence of head Librarians laissez-faire leadership style on job satisfaction of Librarians?

Table 1. Leadership styles commonly adopted by head librarians in tertiary institution libraries in Imo state.

\begin{tabular}{ccc}
\hline Leadership styles & Frequency & Percentage \\
\hline Democratic & 33 & $54 \%$ \\
Autocratic & 18 & $30 \%$ \\
Laissez-faire & 10 & $16 \%$ \\
Total & $\mathbf{6 1}$ & $\mathbf{1 0 0 \%}$ \\
\hline
\end{tabular}

Table 2. Mean rating on the influence of head Librarians democratic leadership style on job satisfaction of librarians.

\begin{tabular}{|c|c|c|c|}
\hline $\mathbf{S} / \mathbf{N}$ & Question Items & Mean & Decision \\
\hline 1 & $\begin{array}{l}\text { The effective communication style adopted by library leadership } \\
\text { promotes librarians participate in administration }\end{array}$ & 2.98 & Agree \\
\hline 2 & $\begin{array}{l}\text { Librarians are happy with their job because library leadership } \\
\text { always fights for their welfare rights }\end{array}$ & 2.98 & Agree \\
\hline 3 & $\begin{array}{l}\text { Ability of leadership to promote interpersonal relationship with } \\
\text { librarians does not create positive work environment }\end{array}$ & 2.23 & Disagree \\
\hline 4 & $\begin{array}{l}\text { The idea of sharing leadership powers/authority with } \\
\text { subordinates help librarians to grow on the job }\end{array}$ & 2.97 & Agree \\
\hline 5 & $\begin{array}{l}\text { Personal talents are recognized and appreciated by leadership } \\
\text { and it makes the librarians to feel happy on their job }\end{array}$ & 3.10 & Agree \\
\hline 6 & $\begin{array}{l}\text { The idea of allowing librarians some degree of autonomy and } \\
\text { creativity on their job does not make them happy }\end{array}$ & 2.15 & Disagree \\
\hline
\end{tabular}


Table 3. Mean rating on the influence of head Librarians autocratic leadership style on job satisfaction of librarians.

\begin{tabular}{|c|c|c|c|}
\hline $\mathbf{S} / \mathbf{N}$ & Question Items & Mean & Decision \\
\hline 7 & $\begin{array}{l}\text { The tendency for leadership to take all decisions does } \\
\text { not make librarians happy with their job }\end{array}$ & 3.38 & Agree \\
\hline 8 & $\begin{array}{l}\text { Library leadership’s attitude of not considering suggestions } \\
\text { discourage relevant contributions by librarians }\end{array}$ & 3.10 & Agree \\
\hline 9 & $\begin{array}{l}\text { Leadership tendency to issue information as instructions, for staff to } \\
\text { comply strictly discourages effective contribution by librarians }\end{array}$ & 2.98 & Agree \\
\hline 10 & $\begin{array}{l}\text { Leadership's use of threat and punishment to achieve library } \\
\text { objectives does not make librarians happy with their jobs }\end{array}$ & 2.30 & Disagree \\
\hline 11 & $\begin{array}{l}\text { Leadership’s inability to fight for the welfare of staff } \\
\text { make librarians’ loose interest on their jobs }\end{array}$ & 2.79 & Agree \\
\hline 12 & $\begin{array}{l}\text { The inability of leadership to hold meetings and discussions before } \\
\text { instructions are issued to staff make librarians happy with their job }\end{array}$ & 2.28 & Disagree \\
\hline
\end{tabular}

Table 4. Mean rating on the influence of head Librarians laissez-faire leadership style on job satisfaction of librarians.

\begin{tabular}{|c|c|c|c|}
\hline $\mathbf{S} / \mathbf{N}$ & Question Items & Mean & Decision \\
\hline 13 & $\begin{array}{l}\text { Leadership’s inability to take necessary decisions does not } \\
\text { affect librarians job satisfaction. }\end{array}$ & 2.10 & Disagree \\
\hline 14 & $\begin{array}{l}\text { The tendency for library leadership to overlook their responsibilities } \\
\text { make librarians' to loose interest on their job. }\end{array}$ & 3.10 & Agree \\
\hline 15 & $\begin{array}{l}\text { Leadership’s inability to discuss or evaluate staff problems } \\
\text { does not promote job satisfaction. }\end{array}$ & 2.94 & Agree \\
\hline 16 & $\begin{array}{l}\text { Inability of head librarians to fight for staff welfare rights } \\
\text { may lead librarians to be dissatisfied with their job. }\end{array}$ & 3.10 & Agree \\
\hline 17 & $\begin{array}{l}\text { Allowing librarians to set goals and work the way they want without } \\
\text { pressure and guidance from leadership, does not promote job satisfaction. }\end{array}$ & 2.89 & Agree \\
\hline 18 & $\begin{array}{c}\text { Leadership’s inability to supervise librarians strictly does not create } \\
\text { undesirable behaviour among them. }\end{array}$ & 2.30 & Disagree \\
\hline
\end{tabular}

Table 4 above, indicates that question items 14, 15, 16 and 17 were rated positive while question items 13 and 18 was rated negative. The mean scores were above and below the criterion mean of 2.50 respectively and this implies that head librarians' laissez-faire leadership style does not ensure librarians' job satisfaction.

\section{Discussion}

From the result of the data analyzed, it is obvious that head librarians in tertiary institution libraries in Imo State adopt the three leadership styles under study. This finding is in agreement with Mgbodile (2004) [36], who asserted that despite different terminologies used by experts to describe management styles of leadership, it has been generally agreed that styles used by men in leadership positions can be put into three main types namely, autocratic, democratic and laissez-faire leadership styles.

The study also found out that democratic leadership style was the commonest style of leadership adopted by head librarians in tertiary institution libraries in Imo State as indicated by $33(54 \%)$ of the respondents. This was followed by autocratic and laissez-faire, as indicated by 18 (30\%) and 10 (16\%) respondents respectively. This finding is in agreement with earlier findings by Ajibade (1990) [37] and Odulade (1999) [38], when they asserted that democratic leadership style is most commonly used leadership style.

The results revealed that democratic leadership style has greater influence on librarians' job satisfaction, followed by autocratic and laissez-faire leadership styles. The influence implies that head librarians who adopt democratic leadership style are most likely to have librarians who are satisfied with their job. This is supported by Obi (2003) [39] who asserted that employees are more satisfied with democratic leadership because their opinions, comments and suggestions are needed for decision making. It also agrees with the findings of Ijaiya (2000) [40] and Ezeuwa (2005) [41], when they concluded that democratic leaders see their subordinates as colleagues and partners in progress with objective ideas for solving organizational problems. 
The findings also revealed that though democratic leadership style is commonly adopted by head librarians, autocratic and laissez-faire leadership styles have influence on the job satisfaction of librarians. The autocratic leader is one who allows the activities of the library organization to revolve around his person. And the problem with the approach is that the leader may neglect other dimensions of leadership which when blended with autocratic style will enhance leadership effectiveness and sustain job satisfaction (Omeka and Onah, 2012) [42]. Head librarians who adopt laissez-faire style in their leadership will likely expect librarians with low level of job satisfaction.

\section{Conclusion and Recommendation}

Based on the findings of the study, it can be concluded that the head librarian's leadership styles have critical influence on job satisfaction of librarians. It also revealed that democratic leadership is the dominant style of leadership that could enhance better job satisfaction for librarians in tertiary institution libraries in Imo State. It is recommended therefore that heads of libraries should try to use a combination of the three styles depending on situations and circumstances in order to enhance better job satisfaction among librarians. Head librarians should involve subordinate librarians in decision making so they can contribute effectively. There is a need for head librarians to delegate some responsibilities with relevant authority to librarians in order to encourage them to learn and grow on the job and through it derive satisfaction on their job.

\section{References}

[1] Fatokun, J.O., Salaam, M.O., Ajegbomogun, F.O. and Adedipe, N. (2010) The Influence of Leadership Style on the Performance of Subordinates in Nigeria Libraries. Library Philosophy and Practice 2010. www.webpages.Uidaho.edu/mbolin/fatokun-salaam-ajegbomogun.htm

[2] Adegbesan, S.O. (2013) Effects of Principals’ Leadership Style on Teachers’ Attitude to Work in Ogun State Secondary Schools, Nigeria. Turkish Online Journal of Distance Education, 14, 14-28.

[3] Northouse, C. (2007) Leadership Theory and Practice. 3rd Edition, Sage Publication Inc., Thousand Oak.

[4] Chukwuma, P.E. and Idris, O.M. (2009) Leadership Management. Journal of Business Administration and Management, 4, 93-96.

[5] Eneh, O.C. (2008) Leadership Common Wrong Choices-A Review. Journal of Business Administration and Management, 2, 86-88.

[6] Nwachukwu, C.C. (2000) Effective Leadership and Productivity. Evidence from a National Survey of Industrial Organizations. African Journal for Study of Social Issues, 1, 38-46.

[7] Vecchio, R. (2007) Leadership: Understanding the Dynamics of Power and Influence in Organizations. University of Notre Dame Press, Notre Dame.

[8] Rezalean, A., Givi, M.E., Givi, H.E. and Nasrabadi (2010) The Relationship between Organizational Justice and Organizational Citizenship Behaviours: The Mediating Role of Organizational Commitment, Satisfaction and Trust. Research Journal of Business Management, 4, 112-120. http://dx.doi.org/10.3923/rjbm.2010.112.120

[9] Smith, K. (2012) Leadership Style and Employee Morale. Oxford University Press, London.

[10] Ekpenyong, S. (2003) Elements of Sociology. Corporate Impressions, Nigeria.

[11] McEachen, I. and Keogh, J. (2007) Nurse Management. McGraw-Hill, New York.

[12] Borkowski, N., Decker, G., Weber, M., Padro, M.A. and Luongu, S. (2011) Leadership Development Initiatives Underline Individual and System Performance in a US Public Healthcare Delivery System. Workplace Learning, 22, 228248.

[13] Haralombus, M. (2001) Sociology Themes in Perspective. Oxford University Press, New Delhi.

[14] Sabnett, B. and Ross, T. (2007) Leadership Frames and Perception of Effectiveness among Health Information Management Programme Directors. Perspectives in Health Information Management, 4, 8. http://www.nebi.nim.gov/pme/articles/PMC2047298

[15] Limsila, K. and Ogunlana, S.O. (2008) Performance and Leadership Outcome Correlates of Leadership Style And subordinate Commitment. Engineering, Construction and Architectural Management, 15, 164-184. http://dx.doi.org/10.1108/09699980810852682

[16] Pearce II, J.A. and Robinson, R.B. (2005) Strategic Management. A.J.T.B.S. Publishers, Delhi.

[17] Kouzes, J.M. and Posner, B.Z. (2002) The Leadership Challenge. Jossey-Bass, San Francisco. 
[18] Gharehbaghi, K. and McManus K. (2003) Effective Construction Management. Leadership and Management in Engineering, 3, 54-55. http://dx.doi.org/10.1061/(asce)1532-6748(2003)3:1(54)

[19] Khandwalla, P.N. (1992) Some Top Management Styles, Their Context and Performance. Organisational and Administrative Science Journal, 7, 21-25.

[20] Vigoda, E. and Cohen, A. (2003) Work Congruence and Excellence in Human Resource Management. Empirical Evidence from the Israel Non-Profit Sector. Public Personnel Administration, 23, 192-216.

[21] Adeyemi, T.O. (2011) Principals’ Leadership Styles and Teachers' Job Performance in Senior Secondary Schools in Ondo State, Nigeria. Current Research Journal of Economic Theory, 3, 84-92.

[22] John, C.N. (2002) Million Leaders Mandate: Notebook One. Equip Publishers, USA.

[23] Mba, J. (2004) Strategic Management Center. Punch publishers, Lagos.

[24] Vroom, V. (2010) Work and Motivation. Wiley Rose, New York.

[25] Fields, D.L. (2002) Taking the Measure of Work: A Guide to Validated Scales for Organizational Research and Diagnosis. Sage Publications, Thousand Oaks.

[26] Hughes, R.L., Gonnett, R.C. and Curphy, G.J. (2006) Leadership, Enhancing the Lessons of Experience. 5th Edition, McGraw-Hill, New York.

[27] Ajayi, A.O. (2012) Leadership Styles in Institutions of Higher Education: A Contingent Approach Nigerian Institute of Management. Journal of Management, 12.

[28] Robbins, S.P., Decenzo, D.A. and Coulter, M. (2010) Fundamentals of Management: Essentials Concepts and Application. 7th Edition, Prentice Hall, Upper Saddle River.

[29] Emery, C.R. and Barker, K.J. (2007) Effect of Commitment, Job Involvement and Teams on Customer Satisfaction and Profit. Team Performance Management, 13, 90-101. http://dx.doi.org/10.1108/13527590710759847

[30] Ribelin, P.J. (2003) Retention Reflects Leadership Style. Nursing Management, 34, 18-19. http://dx.doi.org/10.1097/00006247-200308000-00008

[31] Teller, A., Ayeni, C.O. and Popoola, S.O. (2007) Work Motivation, Job Satisfaction and Organizational Commitment of Library Personnel in Academic and Research Libraries in Oyo State, Nigeria. Library Philosophy and Practice, 9. http://unlib.unl.edu/lpp/tella2.htm

[32] Castillo, J.X. and Cano, J. (2004) Factors Explaining Job Satisfaction among Faculty. Journal of Agricultural Education, 45, 65-74. http://dx.doi.org/10.5032/jae.2004.03065

[33] Omolayo, B.O. and Ajila, C.K. (2012) Leadership Styles and Organizational Climate as Determinants of Job Involvement and Job Satisfaction of Workers in Tertiary Institutions. Business Management Research, 1, 28-36. http://dx.doi.org/10.5430/bmr.v1n3p28

[34] Yarmohammadian, H.M. and Rad, A.M.M. (2006) A Study of Relationship between Managers' Leadership Style and Employees' Job Satisfaction. Leadership in Health Services, 19, 11-28. http://dx.doi.org/10.1108/13660750610665008

[35] Wilkinson, A.D. and Wagner, R.M. (1993) Supervisors Leadership Styles and State Vocational Rehabilitation: Counselor Job Satisfaction and Productivity. Rehabilitation Counselling Bulletin, 37, 15-24.

[36] Mgbodile, T.O., Ed. (2004) Fundamentals in Educational Administration and Planning. Magnet Business Enterprise, Enugu.

[37] Ajibade, T.O. (1990) Principals’ Leadership Styles and Teachers’ Job Performance in Senior Secondary Schools in Ondo State, Nigeria. Current Research Journal of Economic Theory, 3, 84-92.

[38] Odunlade, R.O. (2012) Managing Employee Compensation and Benefits for Job Satisfaction in Libraries and Information Centers in Nigeria. Library Philosophy and Practice, Paper 714. http://unllib.unl.edu/lpp/

[39] Obi, E. (2003) Educational Management: Theory and Practice. Jamoe Enterprise, Enugu.

[40] Ijaiya, N.Y. (2000) Failing Schools' and national Development: Time for Reappraisal of School Effectiveness in Nigeria. Nigerian Journal of Educational Research and Evaluation, 2, 42.

[41] Ezeuwa, L. (2005) Issues in Educational Management. Hipuks Additional Press, Enugu.

[42] Omeka, F.C. and Onah, K.A. (2012) The Influence of Principals’ Leadership Styles on Secondary School Teachers' Job Satisfaction. Journal of Educational and Social Research, 2. 